\title{
SUMMARY OF DWPF ANTIFOAM REQUIREMENTS (U)
}

\author{
by J. C. Marek
}

Westinghouse Savannah River Company

Savannah River Site

Aiken, South Carolina 29808

Other Authors:

This paper was prepared in connection with work done under Contract No. DE-AC09-89SR18035 with the U. S.

Department of Energy. By acceptance of this paper, the publisher and/or recipient acknowledges the U. S.

Government's right to retain a nonexclusive, royalty-free license in and to any copyright covering this paper, along with the right to reproduce and to authorize others to reproduce all or part of the copyrighted paper.

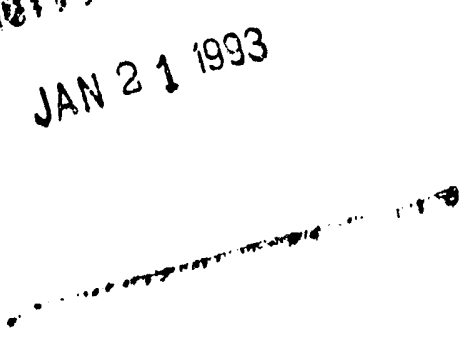




\section{DISCLAIMER}

This report was prepared as an account of work sponsored by an agency of the United States Government. Neither the United States Government nor any agency thereof, nor any of their employees, makes any warranty, express or implied, or assumes any legal liability or responsibility for the accuracy, completeness, or usefulness of any information, apparatus, product, or process disclosed, or represents that its use would not infringe privately owned rights. Reference herein to any specific commercial product, process, or service by trade name, trademark, manufacturer, or otherwise does not necessarily constitute or imply its endorsement, recommendation, or favoring by the United States Government or any agency thereof. The views and opinions of authors expressed herein do not necessarily state or reflect those of the United States Government or any agency thereof.

This report has been reproduced directly from the best available copy.

Available to DOE and DOE contractors from the Office of Scientific and Technical Information, P.O. Box 62, Oak Ridge, TN 37831; prices available from (615) 576-8401, FTS 626-8401.

Available to the public from the National Technical Information Service, U.S. Department of Commerce, 5285 Port Royal Rd, Springfield, VA 22161. 
Keywords: DWPF, Antifoams, Chemical Process Cell, Salt Process Cell, Late Wash Facility, Entrainment

Retention Period: Permanent

\author{
CC: C. T. Randall, 704-T \\ J. T. Carter, 704-1T \\ M. J. Plodinec, 773-A \\ C. W. Hsu, 704-1T \\ A. S. Choi, 704-1T \\ R. E. Eibling, 704-T \\ M. A. Baich, 704-T \\ R. A. Jacobs, 704-T \\ C. J. Bannochie, 704-1T \\ H. E. Shook, 704-1T \\ L. M. LeQ, 704-T \\ K. G. Brown, 704-1T \\ N. D. Hutson, 704-1T \\ H. B. Shah, 704-1T
}

October 12, 1992

TO:

E. W. HOLTZSCHEITER, 773-A

FROM:

J. C. MAREK, 704-T f. C.Mareh

SUMMARY OF DWPF ANTIFOAM REQUIREMENTS (U)

\title{
SUMMARY
}

Documentation of all DWPF process steps where an antifoam is or may be required was requested as a DWPT deliverable item for DWPF Cold Chemical Runs [1]. This report identifies all DWPF process steps where an antifoam is required and process steps where an antifoam may potentially be required. Special solvents and the recommended concentration of active antifoam ingredient are identified as are areas of active development work by DWPT on antifoams for DWPF processing. The report summarizes the current state of knowledge about artifoam use for both DWPF Cold Chemical Runs and for future radioactive operations. Summary charts are provided for quick reference and more details are given in the body of the report.

Excessive foaming in the Salt Processing Cell's Organic Evaporator (OE) could result in sufficient cesium and solids carryover to the Organic Evaporator Condensate Tank (OECT) to preclude meeting the process requirement radionuclide limit in the recovered organic for transfer to the Organic Waste Storage Tank (OWST) outside the 221-S Building. It is recommended that a pneumatic foam detector similar to the one recommended previously for the Precipitate Reactor be installed in the OE before the start of radioactive operations with an alarm to indicate the onset of foaming.

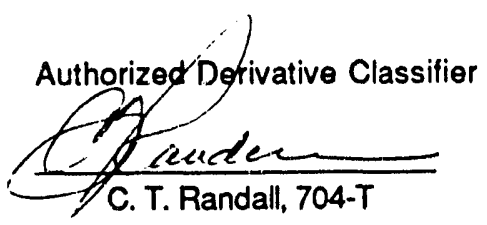




\section{SLUDGE PROCESSING}

\section{Chemical Processing Cell SRAT and SME Vessels}

Foaming and associated solids carryover was a notable problem encountered during Run \#4 of the Full-Scale SRAT/SME at TNX, which resulted in a recommendation to DWPF to provide the capability to add antifoam periodically to both the Sludge Receipt and Adjustment Tank (SRAT) and the Slurry Mix Evaporator (SME) [2]. An antifoam will be required in the SRAT and SME to mitigate foam generation during boiling of these vessels and the associated solids carryover and reduction in decontamination factor $[2,3,4]$. Use of the antifoam is recommended for both DWPF Cold Chemical Runs and for Radioactive Operations. The antifoam used is a water-dilutable emulsion of polydimethylsiloxanes with the tradename Dow Corning 544 Antifoam. It is solventless and therefore $100 \%$ active ingredient. The recommended concentration of the antifoam is $100 \mathrm{ppm}$ by weight (wet basis) for each addition to the SRAT or SME [3,4]. After assaying the mass of antifoam, it should be combined with ten parts by mass of water and mixed to homogenize the antifoam emulsion. The antifoam emulsion should be added to the SRAT contents prior to the acid adjustment of the caustic sludge, prior to the heatup to aqueous boiling, and every 12 - 16 hours during boiling operations in the SRAT [4]. The antifoam emulsion should be added to the SME contents before heating up to aqueous boiling and every 12 - 16 hours during the boiling operations in the SME. (Installation of a pneumatic foam detector in the SRAT and SME vessels was recommended previously by SRTC [4].) The antifoam should also be added to these vessels when the foam detectors are alarming frequently. If foaming persists, the steam flow to the vessel should be reduced appropriately to reduce the vapor flowrate and increase the time for foam bubbles to break. The use of antifoams in the SRAT and SME is summarized in the attached charts.

\section{PRECIPITATE PROCESSING}

\section{Salt Processing Cell Precipltate Reactor (PR)}

An antifoam may be required in the Precipitate Reactor (PR) to mitigate foam generation during boiling of the PR and the associated solids carryover and reduction in decontamination factor $[5,6,7,8]$. Use of the antifoam may be required in either DWPF Cold Chemical Runs or during Radioactive Operations. (Installation of a pneumatic foam detector in the PR vessel was recommended previously by SRTC [8].) It is recommended that antifoam not be routinely added each PR cycle but rather in response to excessive foaming as indicated by the alarming of the PR foam detector. The antifoam used is the same as specified for the Chemical Processing Cell, a water dilutable emulsion of polydimethylsiloxanes with the tradename Dow Corning 544 Antifoam. It is solventless and therefore $100 \%$ active ingredient. The recommended concentration of the antifoam is $100 \mathrm{ppm}$ by weight (wet basis). After assaying the mass of antifoam, it should be combined with ten parts by mass of water and mixed to homogenize the antifoam emulsion. The antifoam emulsion should be added to the PR contents prior to the heatup to aqueous boiling or as dictated by the foam detector. If foaming persists after antifoam addition, the steam flow to the vessel should be reduced appropriately to reduce the vapor flowrate and increase the time for foam bubbles to break. The use of antifoams in the PR is summarized in the attached charts.

\section{Salt Processing Cell Organic Evaporator (OE)}

An antifoam is not recommended for the organic liquid/vapor foam that occasionally forms during the Organic Evaporator (OE) operation [9]. It is recommended that the steam flow to the $O E$ and the liquid level be controlled to avoid generation and foamover in this vessel [9]. This applies to DWPF Cold Chemical Runs and Radioactive Operations. 
Excessive foaming in the $O E$ could result in sufficient cesium and solids carryover to the Organic Evaporator Condensate Tank (OECT) to preclude meeting the process requirement radionuclide limit in the recovered organic for transfer to the Organic Waste Storage Tank (OWST). It is recommended that a pneumatic foam detector similar to the one recommended previously for the Precipitate Reactor be installed in the OE before the start of radioactive operations with an alarm to indicate the onset of foaming.

\section{Low Polnt Precipltate Pump Tank (LPPPT)}

An antifoam (2,4,7,9-tetramethyl-5-decyn-4,7-diol) will be required in the Low Point Precipitate Pump Tank (LPPPT) to mitigate foam generation during preparation and/or storage of prepared simulated precipitate feed for DWPF Cold Chemical Runs $[5,10]$. The simulated precipitate slurry contains potassium and cesium tetraphenylborate solids. The solids, when contacted and mixed with noncondensable vapors such as air, nitrogen, or carbon dioxide under shear, can form a stable foam that, in the absence of a radiation field, can exist for weeks $[11,12]$ and perhaps even years. The foam generation is believed to be caused by the hydrophobic nature of the tetraphenylborate crystals, which migrate to and stabilize at the air-water interface [13]. This foam generation can present extreme operability problems when it occurs [14]. To avoid the formation of foam, it is recommended that the appropriate quantity of 2,4,7,9-tetramethyl-5-decyn-4,7-diol to provide $2000 \mathrm{ppm}$ by weight in the final precipitate feed mixture be added to the LPPPT before the addition of sodium tetraphenyiborate to form the precipitate slurry. The antifoam is sold under the tradename of Surfynol 104 by Air Products Co. The material is $50 \mathrm{wt} \%$ active ingredient in various solvents. The form recommended for use in DWPF Cold Chemical Runs is Surfynol 104E, which is $50 \mathrm{w} \%$ Surfynol 104 dissolved in ethylene glycol solvent. Oher solvents such as isopropyl alcohol (Surfynol 104 PA) are not recommended because of the potential for a mixed fuel system for flammabilty control in the Salt Processing Cell [15]. Fortunately, the foam generated from irradiated precipitate feeds will collapse in a time span of minutes to hours [12] and hence antifoam additions during DWPF Radioactive Operations are unlikely to be needed. However, Waste Management may add Surfynol 104 before the feed is iransferred to DWPF [12].

\section{Precipltate Reactor Feed Tank (PRFT)}

An antifoam will be required for addition to the Precipitate Reactor Feed Tarik if it is necessary to run the HAN process during Radioactive Operations. The antifoam is needed to avoid generation of precipitate foam during the nitrite-destruction with HAN. As the precipitate is fed to the PR, nitrous oxide and carbon dioxide gases liberated from nitrite destruction and carbonate destruction cause a foam similar to that formed from precipitate feeds. The recommended antifoam for addition to the feed is a reaction product of ethylene oxide with 2,4,7,9-tetramethyl-5decyn-4,7-diol. It is sold under the tradename Surfynol 420 by Air Products Co. The recommended concentration in the precipitate feed is $1500 \mathrm{ppm}$ by weight (wet basis) [16]. Surfynol 420 is a liquid at ambient conditions, requires no solvent, and is $100 \%$ active ingredient.

\section{Precipltate Pump Tank In Auxillary Pump Pit}

An antifoam may be required for addition to the precipitate feed in the Late Wash Facility during Radioactive Operations, but this antifoam should not be used routinely (only when absolutely necessary) because it will inhibit benzene sparging in the Recycle Pump Tank (RPT) and the Sludge Pump Tank (SPT) if it is shown to pass through the crossflow filter with the permeate (see next section addressing R\&D activities) [17]. To avoid the formation of foam in the precipitate during the late washing operation, it may be necessary to provide $500 \mathrm{ppm}$ by weight of 2,4,7,9-tetramethyl-5-decyn-4,7-diol in the unwashed precipitate feed in the Precipitate Pump Tank (PPT) of the Auxiliary Pump Pit before initiating the washing operation. The antifoam is sold under the tradename of Surtynol 104 by Air Products Co. The material is 50 wt\% active ingredient in various solvents. The form currently recommended for use is Surfynol 104E, which is $50 \mathrm{wt} \%$ Surfynol 104 dissolved in ethylene glycol solvent. Other solvents such as isopropyl alcohol (Surfynol 104 PA) are not recommended because of the potential for a mixed fuel system for flammabilty control in the Salt Processing Cell [15]. A foam detector was recommended by SRTC as a part of the Late Wash Facility technical bases [17]. 


\section{ANTIFOAM RESEARCH AND DEVELOPMENT ACTIVITIES}

Current research and development efforts by SRTC on antifoams for application in the DWPF are summarized below:

- SRTC is testing alternatives to 2,4,7,9-tetramethyl-5-decyn-4,7-diol (Surfynol 104) antifoam for precipitate feed applications because incorporation of this antifoam in the feed simulants requires a solvent (ethylene glycol in Surtynol 104E) that is not prototypic of the DWPF material balance. Surfynol 420 (reaction product of ethylene oxide with $2,4,7,9-$ tetramethyl-5-decyn-4,7-diol has been found to be effective in the laboratory, requires no solvent because it is a liquid, and is being procured for testing in the Precipitate Hydrolysis Experimental Facility.

0

SRTC is working to quantify the amount of Surfynol 104 that will pass through the crossflow filter in the Late Wash Facility and to assess its impact on the sparging of permeate to remove benzene.

0

SRTC is assessing the degree of foaming during the sparging of late washing permeate to remove benzene.

SRTC is identifying water soluble antifoam agents for testing with precipitate and late washing permeate that will not impact the removal of benzene during sparging. 


\section{REFERENCES}

1) L. F. Landon, "Project Review of the Nitric Acid Flowsheet Recommendation to DWPF and SRTC Deliverables to Support DWPF Cold Chemical Runs", WSRC-RP-92-1063, September 14, 1992.

2) B. A. Hacker, "Foaming and Solids-Carryover in the Full Scale SRAT/SME", DPST-88-381, March 23, 1988.

3) J. C. Marek and S. M. Peters, "Antifoam for DWPF Feed Preparation Processes", WSRC-RP-89-968, September 27, 1989.

4) N. D. Hutson, "Foaming and Foam Detection in the DWPF Chemical Processing Cell (CPC), WSRC-TR-90-0212, May 1, 1990.

5) M. A. Baich, et al., "Defense Waste Processing Facility: Technical Bases for HAN Precipitate Hydrolysis Process I. DWPF Integrated Cold Runs", WSRC-TM-90-11, December, 1990.

6) L. F. Landon, PHEF Task Team, "Executive Summary of HAN Precipitate Hydrolysis Runs in the Precipitate Hydrolysis Experimental Facility", WSRC-RP-89-1, April 3, 1989.

7) S. R. Young et al., "Precipitate Hydrolysis Experimental Facility Campaign Report, Runs 25 - 36", WSRC-RP-89-538, February 2, 1990.

8) J. R. Morrison, "Foaming and Foam Detection in the DWPF Salt Processing Cell Precipitate Reactor", WSRC-RP-89-807, September 1, 1989.

9) J. C. Marek, "Organic Evaporator Operating Experience", WSRC-RP-89-1373, December 18, 1989.

10) J. C. Marek, "Final Wash Precipitate Feed Simulants for DWPF Cold Chemical Runs", WSRC-RP-92-703, May 15, 1992.

11) J. C. Marek, "Agitation in DWPF Precipitate Pump Pit Tanks", DPST-86-237, January 29, 1986.

12) D. D. Walker, "Foam Control in the In-Tank Precipitation Process", DPST-87-853, November 3C, 1987.

13) R. D. Nelson, "Reduced Foaming in Potassium Tetraphenylborate Slurry", Memorandum to J. Kessler, August 23, 1985.

14) J. C. Marek, "Processing the Clunkers in PHEF PHT Feed Material", SRL-PTD-91-106, September 30, 1991.

15) R. A. Jacobs and J. C. Marek, Preliminary Feed Spectication, SRL-PTD-92-008, February 19, 1992.

16) J. C. Marek, experimental results recorded in WSRC-NB-90-175.

17) L. F. Landon and D. L. Fish, "Technical Bases - Late Washing Facility", WSRC-RP-92-793, Rev. 2, September 8, 1992. 


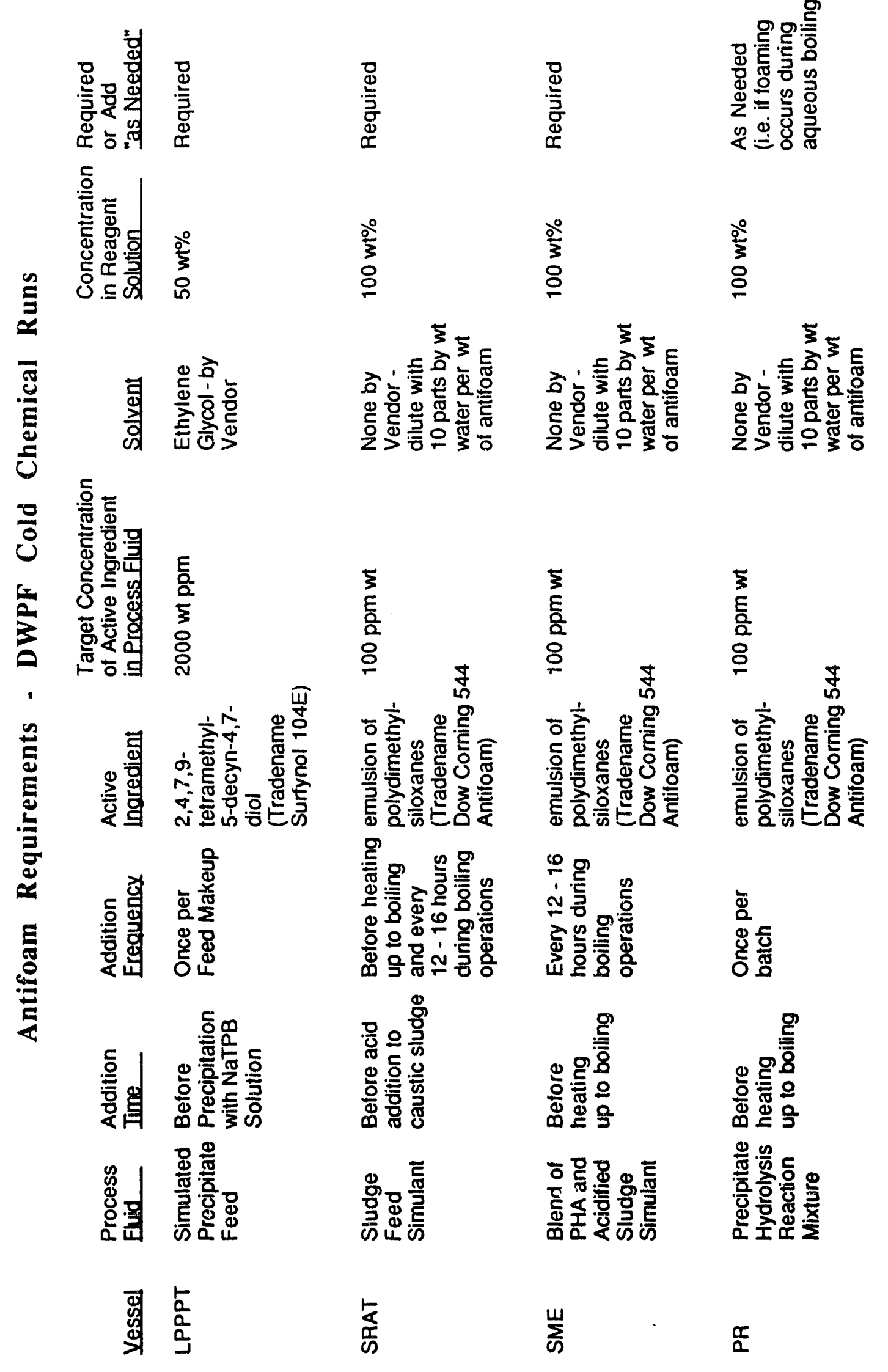




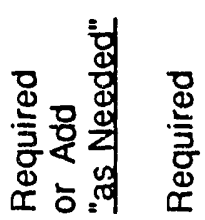

䯧
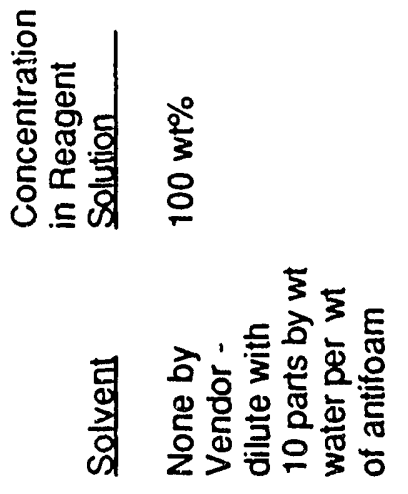

ํํำ

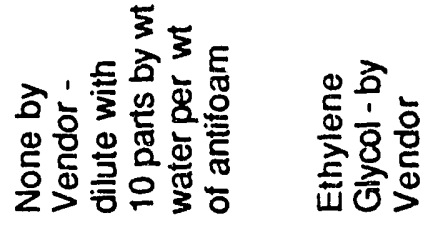

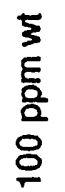

웅

훙형

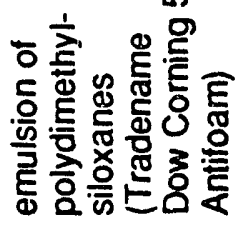
을 은 을

읗형형

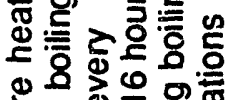
능응ํㅇㅇㅠ

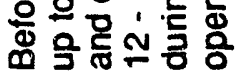

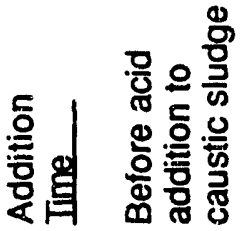

怘 密。

矛秕

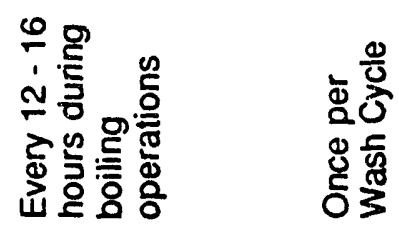

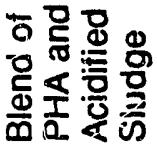

$\sum_{\text {क }}^{山}$

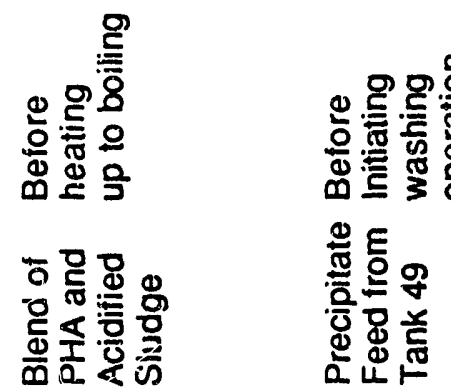

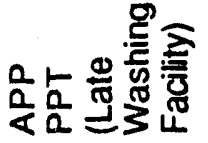

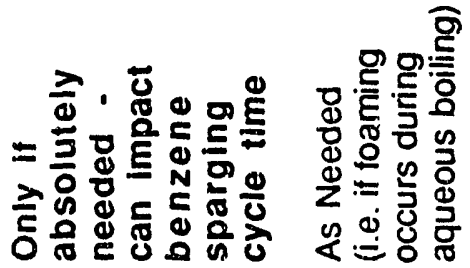

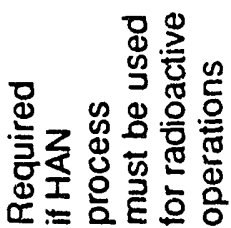

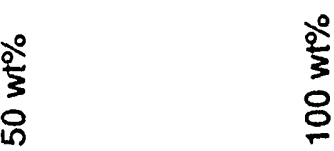

$\begin{array}{ll}\stackrel{2}{9} & \stackrel{9}{3} \\ \vdots & 8\end{array}$

\section{$\frac{20}{3}$}

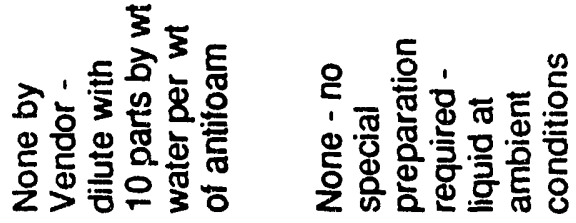

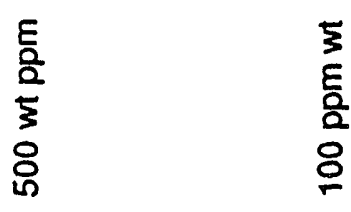

$\xi$
$\Sigma$
$\frac{0}{2}$
8

5
응
8
$\frac{1}{2}$

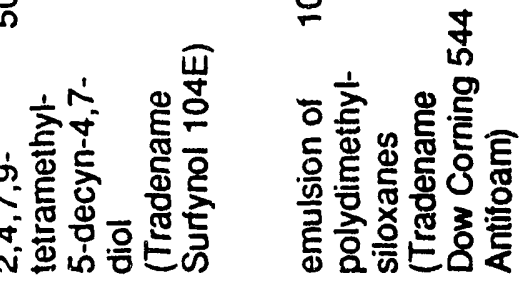

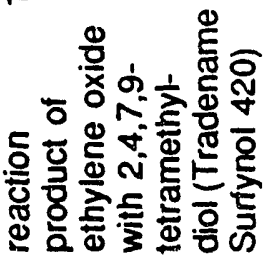

ळ

ญ్ํ웛

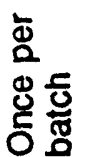

$\frac{5}{0}$

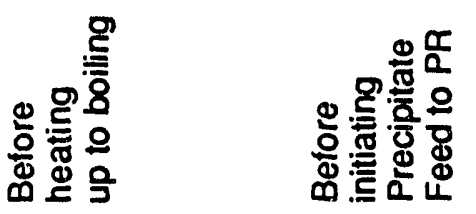

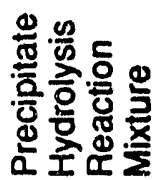

壳형

$\frac{5}{\frac{5}{\alpha}}$ 

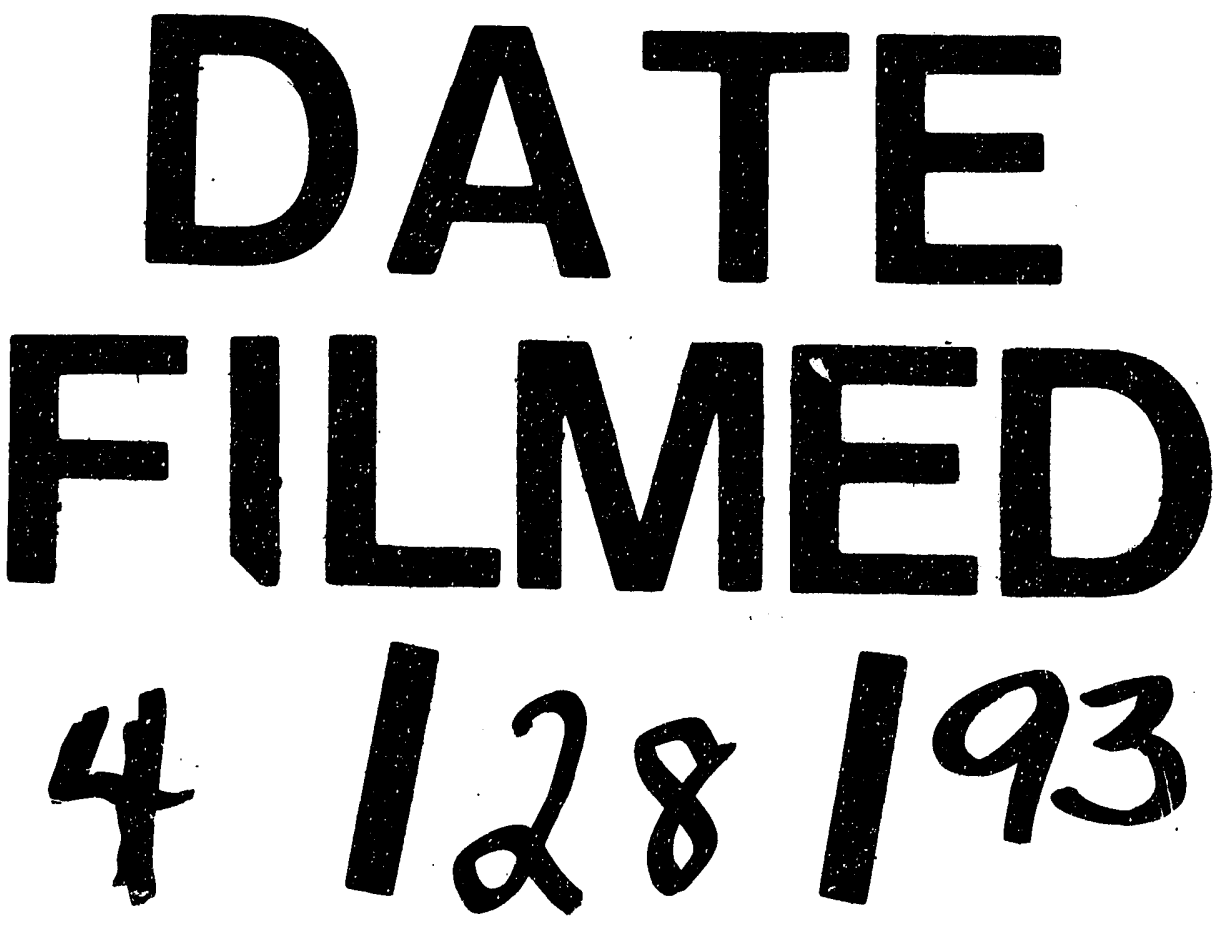
